\title{
Correction to: Can heat and resource availability affect the pest status of African crickets?
}

\author{
Anaïs Chailleux ${ }^{1,2,3} \cdot$ Robert Mwashimaha ${ }^{4} \cdot$ Thibault Nordey ${ }^{1,2,4}$ \\ Published online: 8 July 2020 \\ (C) African Association of Insect Scientists 2020
}

\section{Correction to: International Journal of Tropical Insect Science https://doi.org/10.1007/s42690-020-00189-6}

In the original publication, the given name and the family name of the first author were transposed. The original article has been corrected and the proper representation of the authors' names and their affiliation is also published here.

Publisher's note Springer Nature remains neutral with regard to jurisdictional claims in published maps and institutional affiliations.

The online version of the original article can be found at https://doi.org/ 10.1007/s42690-020-00189-6

\footnotetext{
Anaïs Chailleux

chailleux.anais@gmail.com

1 CIRAD, UPR Hortsys, 34398 Montpellier, France

2 University of Montpellier, Montpellier, France

3 Biopass, CIRAD-IRD-ISRA-UCAD, Dakar, Senegal

4 The World Vegetable Center, Eastern, and Southern Africa,

P.O. Box 10, Duluti, Arusha, Tanzania
} 